\title{
BIOCHEMICAL STUDIES OF HIPPOCAMPAL GENE EXPRESSION OF BRAIN-DERIVED NEUROTROPIC FACTOR AND TOLL-LIKE RECEPTOR-4 IN DIABETIC RATS EXPOSED TO CHRONIC STRESS: EFFECTS OF ANTIDEPRESSANT DRUGS
}

\author{
SAWSAN ABOUL-FOTOUH ${ }^{1,2}$, DOAA HASSAN ${ }^{3}$, MOHAMED HABIB ${ }^{1 *}$, AHMED IBRAHIM AMIN ${ }^{4}$, \\ SAMAR KAMAL KASSIM ${ }^{5}$, AMR SAAD MOHAMED ${ }^{4}$
}

${ }^{1}$ Department of Pharmacology, Faculty of Medicine, Ain Shams University, Cairo, Egypt. ${ }^{2}$, Clinical Pharmacology Unit, Faculty of Medicine, Ain Shams University, Cairo, Egypt. ${ }^{3}$ Central Laboratories, Ministry of Health, Cairo, Egypt. ${ }^{4}$ Department of Chemistry,

Faculty of Science, Cairo University, Cairo, Egypt. ${ }^{5}$ Department of Medical Biochemistry and Molecular Biology, Faculty of Medicine, Ain Shams University, Cairo, Egypt. Email: Mohamed.habib@med.asu.edu.eg

Received: 25 July 2017, Revised and Accepted: 31 October 2017

\section{ABSTRACT}

Objective: Depression and diabetes are closely associated in a reciprocal manner, leading to significant morbidity and mortality with an evidence of a pro-inflammatory state underlying pathophysiology of both diseases. Unfortunately, little information is available about the effects of antidepressant drugs on hippocampal brain-derived neurotrophic factor (BDNF) and toll-like receptor-4 (TLR-4) expression in diabetes.

Methods: We investigated the effect of chronic administration of fluoxetine (FLU) and imipramine (IMIP) on behavioral, metabolic, and inflammatory abnormalities in diabetic and non-diabetic rats exposed to chronic restraint stress (CRS).

Results: Both diabetes and CRS induced depressive-like behavior which was more prominent in diabetic/depressed rats; this was reversed by chronic treatment with FLU and IMIP. Diabetic and non-diabetic rats exposed to CRS showed a significant increase in hippocampal expression of TLR-4 and pro-inflammatory cytokines alongside a decrease in BDNF expression. FLU and IMIP ameliorated these inflammatory abnormalities.

Conclusion: Diabetes mellitus (DM) and chronic stress induced a depressive-like behavior associated with an increase in hippocampal expression of TLR-4, tumor necrosis factor- $\alpha$, and interleukin-1ß with a significant correlation to decreased BDNF expression. FLU and IMIP showed comparable effects regards the improvement of depressive and inflammatory abnormalities associated with DM.

Keywords: Fluoxetine, Imipramine, Chronic restraint stress, Depression, Diabetes mellitus, Toll-like receptor-4, Brain-derived neurotrophic factor.

(C) 2018 The Authors. Published by Innovare Academic Sciences Pvt Ltd. This is an open access article under the CC BY license (http://creativecommons. org/licenses/by/4. 0/) DOI-ttp://dx.doi.org/10.22159/ajpcr.2018.v11i1.21593

\section{INTRODUCTION}

Depression and diabetes are closely related in a reciprocal manner constituting a major public-health problems and causing a significant morbidity and mortality [1,2]. The incidence of depression is increased among people with type 2 diabetes mellitus (DM) [3]. Depression is associated with poor glycemic control, decreased compliance to treatment, and increased diabetic vascular complications [4]. On the other hand, there are many reports about the altered response to antidepressants in diabetics [5]. Antidepressants, in turn, have an impact on DM with several studies reporting increased DM risk with paroxetine and fluvoxamine [6] in contrast to a hypoglycemic effect with fluoxetine (FLU), while other studies failed to confirm this finding and others reported a worsening of glycemic control [7]. Indeed, the effect of different antidepressant drugs on glycemic control in DM is quite controversial.

Brain-derived neurotrophic factor (BDNF), an important neurotrophic factor exerting neuroprotective effects [8], has drawn attention as a pivotal player in the pathogenesis of depression [9] showed decreased levels in serum of diabetic patients and animals, and this was associated with a higher rate of complications [10]. Collectively, the decreased BDNF may be involved in the pathogenesis of both depression and DM [11].

The expression of toll-like receptor (TLR) has been detected in various types of cells including brain cells [12]. They mediate innate immune response in part through nuclear factor- $\mathrm{\kappa B}$ and subsequent cytokine production [13], and this has been reported to participate in inflammatory and autoimmune disease in the central nervous system [14]. In addition, high glucose and saturated fatty acids noticed with DM have been reported to induce TLR-4 activation [15]. Our previous work has reported increased aortic TLR-4 expression in diabetic rats exposed to chronic restraint stress (CRS) with significant correlation to the development of vascular dysfunction and atherosclerotic changes [16].

In general, stress is thought to modulate the immune system through a TLR4-dependent mechanism, and this reinforces the importance of inhibiting TLR-4 activation pathway as an effective approach for prevention and treatment of stress-induced immune dysregulation [17]. Unfortunately, there is little available data on the hippocampal expression of TLR-4 in depressed diabetic subjects and its relation to BDNF.

In the present work, we investigated the effects of chronic treatment with FLU and imipramine (IMIP) on depressive-like behavior and hippocampal expression of BDNF, TLR4, tumor necrosis factor- $\alpha$ (TNF- $\alpha$ ), and interleukin (IL-1 $\beta$ ) in diabetic and non-diabetic rats exposed to CRS. This is to study the effect of two different antidepressant drugs on hippocampal neuroinflammation that has been proposed by many studies as a corner stone in the pathogenesis of depression. This is also to justify the preference of one antidepressant over the other in the management of comorbid depression with diabetes. To the best of our knowledge, this is the first work to assess TLR-4 and BDNF expression in the hippocampus of rats exposed to a combined model of DM and depression. 


\section{METHODS}

\section{Animals}

A total of 92 male Wistar rats weighing 170-200 g purchased from the National Research Centre (Dokki, Giza, Egypt) with 1 week acclimatization period before the experiment. Constant environmental conditions were established for all rats as regards: Temperature $\approx 25^{\circ} \mathrm{C}$, relative humidity $50-60 \%$, and $12 \mathrm{~h}$ light/dark cycle (lights at $6 \mathrm{am}$ - off $6 \mathrm{pm}$ ). All experimental procedures were performed in accordance with the European Community guidelines for the use of experimental animals (1986) and approved by the Research Ethics Committee of Faculty of Medicine, Ain Shams University (FMASU-REC). The Number of approval is FWA 00006445.

\section{Experimental models}

\section{Model of type 2 diabetes}

Rats were fed with high-fat diet for 2 weeks, followed by a single intraperitoneal (IP) injection of $35 \mathrm{mg} / \mathrm{kg}$ streptozotocin "STZ" (SigmaAldrich Chemicals Co., Germany) dissolved in $0.1 \mathrm{M}$ sodium citrate buffer $(\mathrm{pH}=4.4)$. Rats received $5 \%$ sucrose solution orally for $48 \mathrm{~h}$ after STZ injection to prevent hypoglycemia. After that, tail blood samples were obtained and blood glucose concentrations were determined using gluco-check (Accu-Chek Active, Germany). Rats having blood glucose levels above $200 \mathrm{mg} / \mathrm{dl}$ were considered diabetic [18].

\section{CRS model}

CRS was conducted using Plexiglas restrainers $(25 \mathrm{~cm} \times 8 \mathrm{~cm})$ which are not only wide enough to allow comfortable breathing with air vents at the nasal end but also narrow enough to restrict rat's movement. Rats were placed in the restrainers for $4 \mathrm{~h}(9: 00 \mathrm{am}$ to 1:00 pm) per day for 6 weeks $[19,20]$.

\section{Treatments and experimental groups}

The 92 rats were divided into 2 main groups. The first group was non-diabetic rats, which were further subdivided into 4 subgroups: The naïve group $(\mathrm{n}=10)$; not exposed to $\mathrm{CRS}$, CRS vehicle-treated group ( $\mathrm{n}=11)$; exposed to CRS for 6 weeks and received IP injection of saline, CRS/FLU-treated group ( $\mathrm{n}=14)$; received FLU hydrochloride (Sigma-Aldrich Chemicals Co., Germany) dissolved in saline in a dose of $10 \mathrm{mg} / \mathrm{kg} / \mathrm{d}$ IP [21], and CRS/IMIP-treated group ( $\mathrm{n}=14)$; received IMIP hydrochloride (Sigma-Aldrich Chemicals Co., Germany) dissolved in saline in a dose of $10 \mathrm{mg} / \mathrm{kg} / \mathrm{d}$ IP [22]. The second group was the diabetic group which was also subdivided into 4 subgroups: The control/DM group ( $\mathrm{n}=10$ ); not exposed to CRS, DM/CRS vehicle-treated group ( $\mathrm{n}=9$ ); exposed to CRS for 6 weeks and received IP injection of saline, DM/CRS/FLU-treated group $(\mathrm{n}=12)$; received FLU, and DM/ CRS/IMIP-treated group $(\mathrm{n}=12)$; received IMIP. All treatments were given during the past 3 weeks of CRS protocol. All treatments were introduced during the light phase of the light/dark cycle.

\section{Behavioral tests}

\section{Forced swimming test (FST) [23]}

During FST, rats were allowed to swim in a vertical-Plexiglas cylinder (diameter $22.5 \mathrm{~cm}$, height $50 \mathrm{~cm}$ ) filled with fresh water to the level of $35 \mathrm{~cm}$ at $\approx 25^{\circ} \mathrm{C}$ for 2 successive days. On the $1^{\text {st }}$ day, rats were allowed to swim for $15 \mathrm{~min}$. On the $2^{\text {nd }}$ day, rats were reexposed to the forced swimming for $5 \mathrm{~min}$, and their behavior was recorded. Passive behavior (immobility time during which the animal floated on the surface, making only movements necessary to keep it afloat) and active behavior (struggling and swimming times) were analyzed. Depressive behavior was indicated by the ratio of passive to active behavior.

\section{Social interaction test (SIT)}

Two weights-matched rats from the same subgroup were placed into a chamber (30 × $30 \times 60 \mathrm{~cm}$; width, length, and height, respectively) with the floor covered with wood shavings for $10 \mathrm{~min}$. We recorded the time spent in active social behavior for each rat separately. This test is used to test the generalized anxiety behavior which is indicated by decreased active social behavior, including allogrooming, sniffing, following, and crawling under and over the partner [24].
Biochemical measurements of TNF- $\alpha$, IL-1ß, TLR-4, and BDNF proteins in hippocampal homogenate

TNF- $\alpha$, IL-1 $\beta$, TLR-4, and BDNF proteinswere determined in hippocampal homogenate using rat TNF- $\alpha$ enzyme-linked immunosorbent assay (ELISA) kit (Quantikine, USA), rat IL-1 $\beta$ ELISA kit (Kamiya Biomedical, USA), rat TLR-4 ELISA kit (MyBioSource, USA), and rat BDNF ELISA kit (MyBioSource, USA) according to the manufacturer's instructions. Absorbance was measured at $450 \mathrm{~nm}$ and the lower limit of detection was $12.5 \mathrm{pg} / \mathrm{ml}, 15.6 \mathrm{pg} / \mathrm{ml}, 0.625 \mathrm{ng} / \mathrm{ml}$, and $31.2 \mathrm{pg} / \mathrm{ml}$, respectively. The protein content of hippocampal homogenate was determined using the Bradford method [25].

Estimation of BDNF and TLR-4 gene expression by semiquantitative reverse transcriptase polymerase chain reaction (RTPCR) technique in the hippocampal tissue

Extraction of total RNA from the hippocampal tissue of the study groups was performed using TriFast TM in the presence of the inhibitor of RNase activity (PEQLAB Biotechnologie, GmbH, Germany) according to the manufacturer's protocol. cDNA was synthesized using reaction mix: GoTaq ${ }^{\circledR}$ Green Master Mix (Promega, USA). Specific PCR primers (Metabion international AG, Germany) were used in RT-PCR; BDNF sense primer 5'-CATAACCCCGCACACTCTGT-3' and antisense ${ }^{\prime}$-TCGTCAGACCTCTCGAACCT-3' TLR-4 sense primer $5^{\prime}$ - AGTTGGCTCTG- CCAAGTCTCAGAT- $3^{\prime}$ and antisense 3-'TGGCACTCATCAGGATGACACCAT-5'. $\quad \beta$-actin sense primer 5 -ACCACAGCTGAGAGGGAAATCG-3' and antisense Primer 3'-AGAGGTC-TTTACGGATGTCAACG-5'. The synthesized cDNA was amplified by PCR with both upstream and downstream primers. The thermal cycle profile used for the amplification of BDNF was 28 cycles at $94^{\circ} \mathrm{C}$ for $1 \mathrm{~min}$ (denaturation), $55^{\circ} \mathrm{C}$ for $1 \mathrm{~min}$ (annealing), and $72^{\circ} \mathrm{C}$ for $1 \mathrm{~min}$ (extension). TLR4 was recycled for 35 cycles at $95^{\circ} \mathrm{C}$ for $10 \mathrm{~s}$, $58-61^{\circ} \mathrm{C}$ for $15 \mathrm{~s}$, and $72^{\circ} \mathrm{C}$ for $20 \mathrm{~s}$. ß-actin was recycled for 22 cycles at $94^{\circ} \mathrm{C}$ for $1 \mathrm{~min}, 62^{\circ} \mathrm{C}$ for $30 \mathrm{~s}$, and $72^{\circ} \mathrm{C}$ for $2 \mathrm{~min}$.

PCR product sizes for $\beta$ actin was found at $180 \mathrm{bp}$, BDNF product size was found at $135 \mathrm{bp}$ while TLR- 4 was found at $250 \mathrm{bp}$. The PCR products were resolved on a $2 \%$ agarose gel and visualized by ethidium bromide staining. The staining intensity was evaluated using the molecular analyst software (Gel-pro 3.1, USA). The gel was visualized using ultraviolet trans-illuminator and subsequently visualized and photographed by the Gel Documentation System (Gel Doc EQ, BioRad Laboratories, USA). Results were expressed as relative densitometric units of BDNF and TLR-4 gene expression in percentage (\%), normalized to the values of $\beta$-actin MRNA used as an internal control. Semi-quantitation was done using "Quantity One", computer program software version 4.6.3, (BioRad Laboratories, USA).

\section{Statistical analysis}

The results were expressed as mean \pm SEM, and statistical analysis was performed using computer program SPSS, version 17.0 (SPSS, Chicago, IL, USA). Data were analyzed by two-way analysis of variance (ANOVA) followed by Bonferroni's test post-hoc for intergroup comparisons. Pearson's correlation coefficient was used to assess the correlation between the expression of BDNF and TLR-4 with the level of inflammatory markers (TNF- $\alpha$ and IL-1ß) in the hippocampus. Differences were considered statistically significant at $\mathrm{p}<0.05$.

\section{RESULTS}

\section{Effect of tested drugs on FST and SIT}

Table 1 shows that the induction of type 2 diabetes produced depressive-like symptoms in Wistar rats, indicated by the significant increase in passive/active behavior in FST and active interaction time in $\operatorname{SIT}\left(\mathrm{F}_{(1,84)}=11.36, \mathrm{p}=0.0011 ; \mathrm{F}_{(1,84)}=21.94, \mathrm{p}<0.0001\right.$, respectively). Exposure to CRS significantly increased passive/active behavior in FST and decreased the active interaction time in SIT $(p<0.001)$ in both diabetic and non-diabetic rats compared to control groups. Two-way ANOVA reveals that chronic treatment with antidepressants, FLU, and IMIP, significantly reversed CRS-induced behavioral changes in FST and $\operatorname{SIT}\left(\mathrm{F}_{(3,84)}=28.26, \mathrm{p}<0.0001 ; \mathrm{F}_{(3,84)}=23.55, \mathrm{p}<0.0001\right.$, respectively $)$ 
Table 1: Effects of FLU and IMIP on forced swimming and SIT behavioral changes in diabetic and non-diabetic rats exposed to CRS

\begin{tabular}{lll}
\hline & $\begin{array}{l}\text { Passive/active } \\
\text { behavior in FSTs }\end{array}$ & $\begin{array}{l}\text { Active interaction } \\
\text { time in SIT (s) }\end{array}$ \\
\hline $\begin{array}{l}\text { Non-diabetic rats } \\
\text { Control (n=10) }\end{array}$ & $0.2297 \pm 0.0107$ & $129.6 \pm 8.68$ \\
CRS (n=11) & $0.3642 \pm 0.0169^{* * *}$ & $65.55 \pm 7.06^{* * *}$ \\
CRS+FLU (n=14) & $0.2460 \pm 0.0114^{\# \# \#}$ & $100.4 \pm 10.57^{\#}$ \\
CRS+IMI (n=14) & $0.2800 \pm 0.0137^{\# \# \#}$ & $113.7 \pm 6.65^{\# \# \#}$ \\
Diabetic rats & & \\
Control (n=10) & $0.2795 \pm 0.0115^{\$ \$ \$}$ & $75.00 \pm 14.20^{\$ \$ \$}$ \\
CRS (n=9) & $0.3802 \pm 0.0150^{* * *}$ & $14.33 \pm 2.34^{* * *}$ \\
CRS+FLU (n=12) & $0.2867 \pm 0.0079^{\# \# \#}$ & $92.42 \pm 9.36^{\# \# \#}$ \\
CRS+IMI (n=12) & $0.3021 \pm 0.01646^{\# \# \#}$ & $107.8 \pm 6.93^{\# \# \#}$ \\
\hline
\end{tabular}

Data are mean \pm SEM of $9-14$ animals per group. ${ }^{* * *} \mathrm{p}<0.001$ versus control group, ${ }^{\mathrm{p}}<0.05, \# \# \mathrm{p}<0.001$ versus CRS group by two-way ANOVA with Bonferroni's post hoc test. ${ }^{\$ \$} \mathrm{p}<0.001$ diabetic versus non-diabetic control rats, ANOVA: Analysis of variance, FLU: Fluoxetine, IMIP: Imipramine, CRS: Chronic restraint stress, FST: Forced swimming test, SIT: Social interaction test

in both diabetic and non-diabetic rats compared to vehicle-treated groups.

Effect of tested drugs on hippocampal TNF- $\alpha$ and IL-1ß protein As shown in Fig. 1a and b, diabetic rats showed a significant increase in the hippocampal level of the pro-inflammatory cytokine, TNF- $\alpha$ $(\mathrm{p}<0.05)$ compared to the control non-diabetic group. Exposure to CRS induced a significant increase in hippocampal TNF- $\alpha$ and IL-1ß in both non-diabetic $(\mathrm{p}<0.001$ and $\mathrm{p}<0.001)$ and diabetic rats $(\mathrm{p}<0.01$ and $\mathrm{p}<0.001$, respectively) in contrast to control groups. Chronic treatment with FLU significantly decreased hippocampal TNF- $\alpha$ and IL- $1 \beta$ in both non-diabetic $(\mathrm{p}<0.01$ and $\mathrm{p}<0.001)$ and diabetic rats $(p<0.001$ and $p<0.01$, respectively); chronic treatment with IMIP was able to significantly decrease IL-1ß in both non-diabetic $(p<0.001)$ and diabetic rats $(\mathrm{p}<0.01)$. IMIP also produced a significant decrease in hippocampal TNF- $\alpha$ level although this was only significant in diabetic rats $(\mathrm{p}<0.001)$ compared to vehicle-treated group $\left(\mathrm{F}_{(3,56)}=19.49\right.$, $\left.\mathrm{p}<0.0001 ; \mathrm{F}_{(3,56)}=21.60, \mathrm{p}<0.0001\right)$ for TNF- $\alpha$ and IL-1ß, respectively.

Effect of tested drugs on hippocampal BDNF and TLR-4 gene expression

As shown in Figs. $2 \mathrm{a}$ and $\mathrm{b}, 3 \mathrm{a}$ and $\mathrm{b}$, diabetic rats showed $\mathrm{a}$ significant decrease in hippocampal BDNF with an increase in TLR-4 gene expression $\left(\mathrm{F}_{(1,40)}=84.57, \mathrm{p}<0.0001 ; \mathrm{F}_{(1,40)}=41.29, \mathrm{p}<0.0001\right.$, respectively). CRS induced a significant decrease in BDNF ( $\mathrm{p}<0.001$, $\mathrm{p}<0.05)$ and increase in TLR-4 $(\mathrm{p}<0.05, \mathrm{p}<0.001)$ gene expression in both non-diabetic and diabetic rats, respectively, in contrast to control groups. Chronic FLU treatment significantly increased BDNF and decreased TLR-4 gene expression in both non-diabetic $(\mathrm{p}<0.001$, $\mathrm{p}<0.05)$ and diabetic rats $(\mathrm{p}<0.01, \mathrm{p}<0.001)$, respectively. The chronic IMIP treatment produced a significant increase in BDNF in both non-diabetic $(\mathrm{p}<0.001)$ and diabetic rats $(\mathrm{p}<0.01)$. IMIP produced a significant decline in TLR-4 gene expression only in diabetic rats as compared to vehicle-treated group $(\mathrm{p}<0.001)\left(\mathrm{F}_{(3,40)}=47.57, \mathrm{p}<0.0001\right.$; $\left.\mathrm{F}_{(3,40)}=9.49, \mathrm{p}<0.0001\right)$.

Effect of tested drugs on hippocampal BDNF and TLR-4 protein expression

As shown in Fig. 4a and b, diabetic rats showed a significant decrease in hippocampal BDNF with an increase in TLR-4 protein $\left(\mathrm{F}_{(1,40)}=6.47\right.$, $\left.\mathrm{p}<0.05 ; \mathrm{F}_{(1.40)}=31.95, \mathrm{p}<0.0001\right)$. Exposure to CRS in non-diabetic and diabetic rats induced a significant decrease in BDNF protein $(\mathrm{p}<0.01$, $\mathrm{p}<0.05)$ and increase in TLR-4 protein $(\mathrm{p}<0.001, \mathrm{p}<0.001)$ in contrast to control groups. Chronic treatment with FLU significantly $(\mathrm{p}<0.001)$ increased BDNF protein and decreased TLR-4 protein. In addition, chronic IMIP treatment increased BDNF protein $(\mathrm{p}<0.05, \mathrm{p}<0.001)$ and decreased TLR- 4 protein $(p<0.001, p<0.001)$ in both non-diabetic

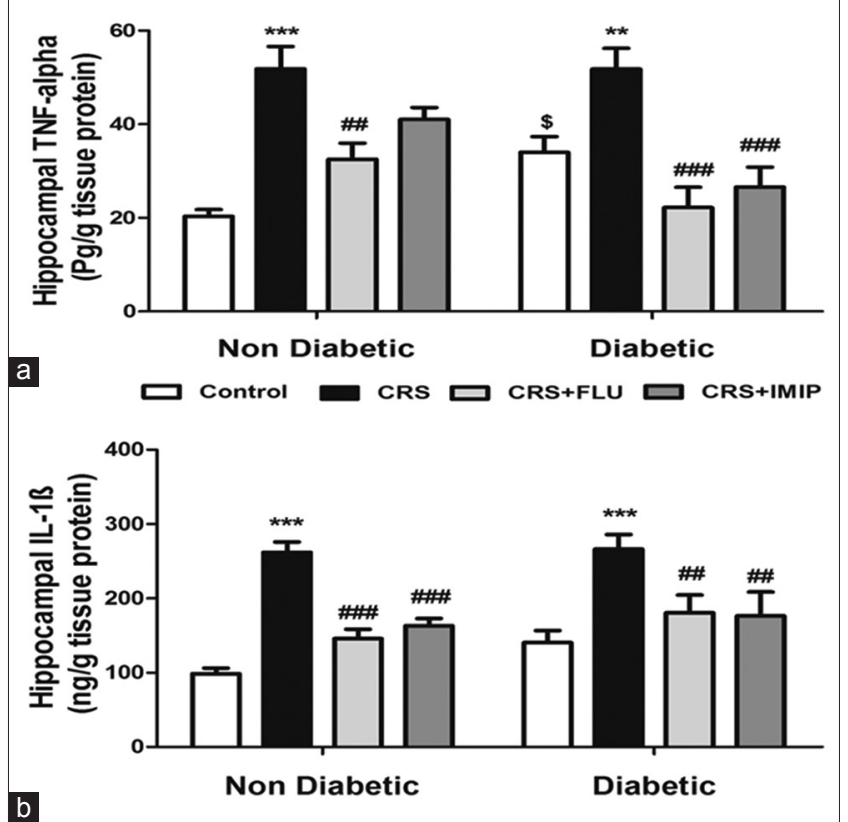

Fig. 1: ( $a$ and $b$ ) Effects of fluoxetine and imipramine on hippocampal tumor necrosis factor- $\alpha$, and interleukin-1 $\beta$ protein levels by enzyme-linked immunosorbent assay technique in non-diabetic and diabetic rats exposed to chronic restraint stress (CRS). Data are mean \pm SEM $(\mathbf{n}=8) .{ }^{* *} \mathbf{p}<0.01,{ }^{* * *} \mathbf{p}<0.001$ versus control group, ${ }^{\# \#} \mathbf{p}<0.01$, \#\#\# $\mathrm{p}<0.001$ versus CRS group by two-way analysis of variance with Bonferroni's post hoc test. ${ }^{\$} \mathrm{p}<0.05$, diabetic versus non-diabetic control rats
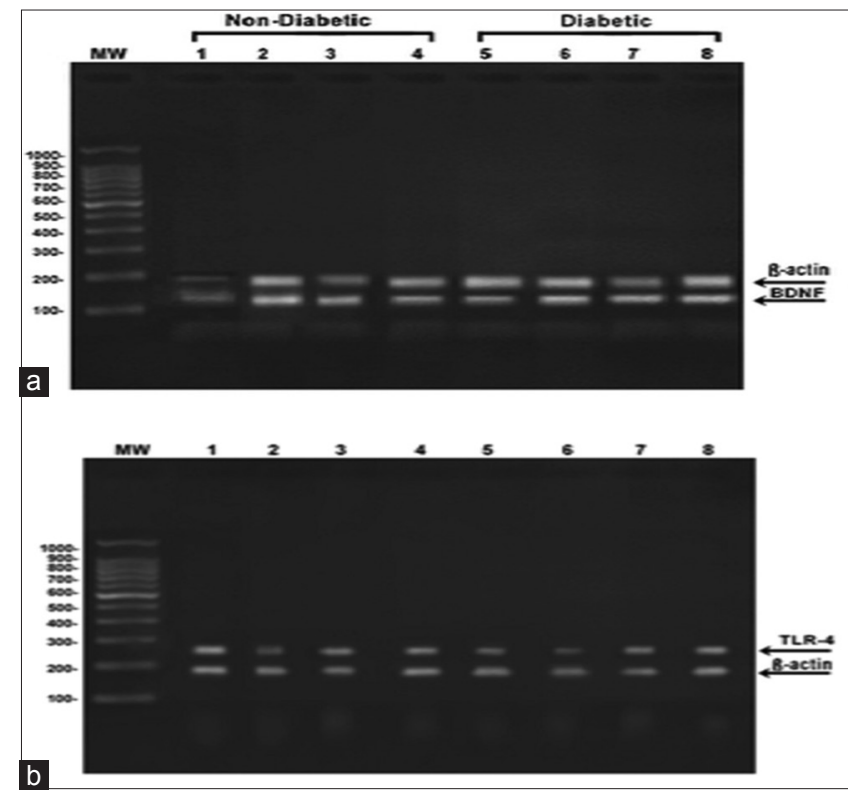

Fig. 2: ( $a$ and b) Ethidium bromide-stained agarose gel electrophoresis showing the amplified reverse transcriptasepolymerase chain reaction products of brainderived neurotrophic factor (135 bp) and toll-like receptor-4 (250 bp) with $\beta$-actin (180 bp) as an internal standard from hippocampal tissue homogenates of Wistar rats. First lane: Molecular weight ladder standard. Lane 1 - control non-diabetic group, Lane 2 - non-diabetic/CRS/vehicle-treated group, Lane 3 - non-diabetic/CRS/FLU-treated group, Lane 4 - non-diabetic/ CRS/IMIP-treated group, Lane 5 - control diabetic group, Lane 6 - diabetic/CRS/vehicle-treated group, Lane 7 - diabetic/CRS/FLUtreated group, Lane 8 - diabetic/CRS/IMIP-treated group 


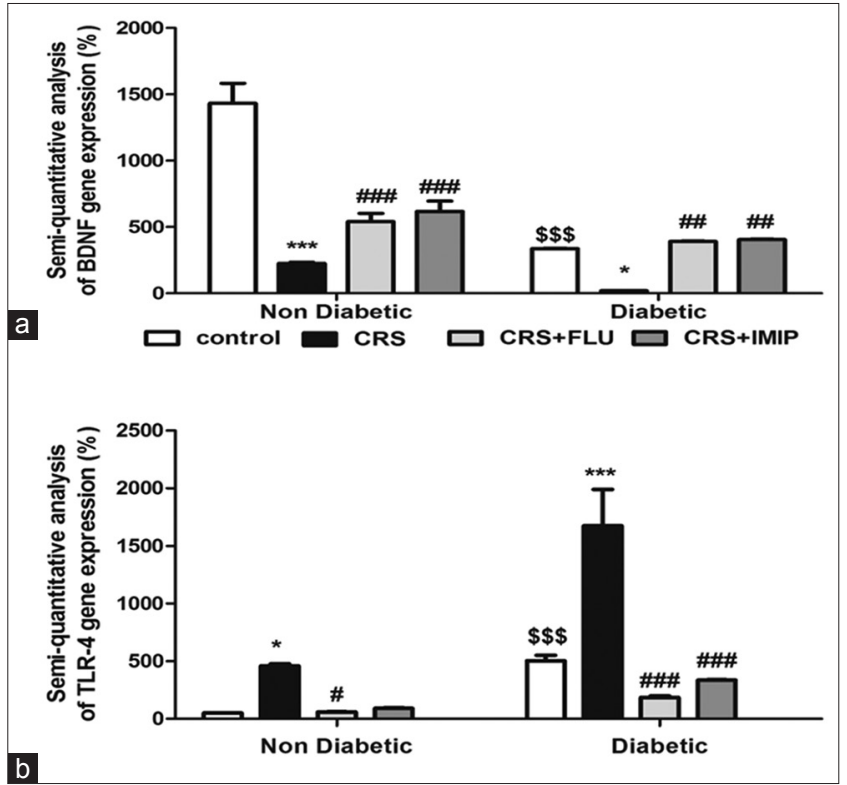

Fig. 3: (a and b) Effects of fluoxetine and imipramine on hippocampal brain-derived neurotrophic factor and tolllike receptor-4 gene expression (mRNA) as \% normalized by $\beta$-actin quantity using semi-quantitative reverse transcriptase polymerase chain reaction in diabetic and non-diabetic rats exposed to chronic restraint stress (CRS). Data are mean \pm SEM $(\mathrm{n}=6) .{ }^{*} \mathbf{p}<0.05,{ }^{* * *} \mathrm{p}<0.001$ versus control group, ${ }^{*} \mathrm{p}<0.05$, ${ }^{\# \#} \mathbf{p}<0.01, \# \# \mathbf{p}<0.001$ versus CRS group by two-way analysis of variance with Bonferroni's post hoc test. ${ }^{\$ \$ \$} \mathbf{p}<\mathbf{0 . 0 0 1}$, diabetic versus non-diabetic control rats

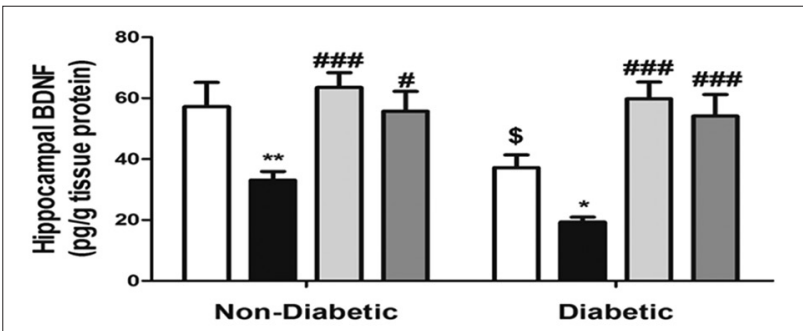

a CCONTROL CRS $\square$ CRS+FLU C CRS+IMIP

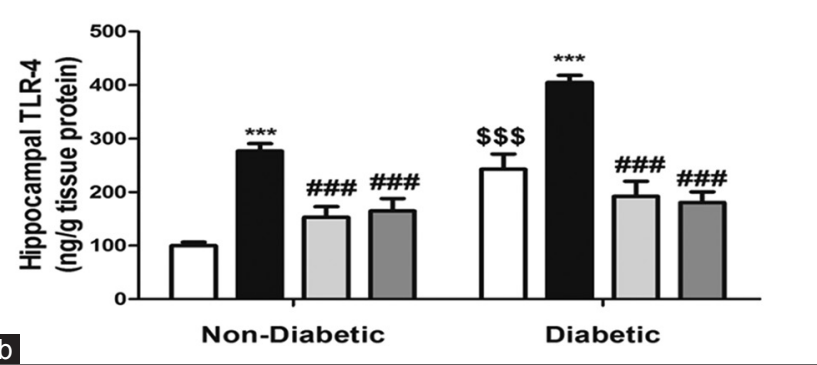

Fig. 4: ( $a$ and $b$ ) Effects of fluoxetine and imipramine on hippocampal brain-derived neurotrophic factor and toll-like receptor-4 protein expression by enzyme-linked immunosorbent assay in diabetic and non-diabetic rats exposed to chronic restraint stress (CRS). Data are mean \pm SEM $(n=6) .{ }^{*} p<0.05$, ${ }^{* *} \mathbf{p}<0.01,{ }^{* * *} \mathbf{p}<0.001$ versus control group, ${ }^{\#} \mathbf{p}<0.05,{ }^{\# \# \#} \mathbf{p}<0.001$ versus CRS groupby two-way ANOVA with Bonferroni's post hoc test. ${ }^{\$} \mathbf{p}<0.05,{ }^{\$ \$ \$} \mathbf{p}<0.001$ diabetic versus non-diabetic control rats

and diabetic rats as compared to vehicle-treated group. $\left(\mathrm{F}_{(3,40)}=16.02\right.$, $\left.\mathrm{p}<0.0001 ; \mathrm{F}_{(3,40)}=34.15, \mathrm{p}<0.0001\right)$ for BDNF and TLR-4, respectively.
As depicted in Figs. 5a-c and 6a and b, statistical analysis by Pearson's correlation coefficient reveals that hippocampal BDNF protein expression significantly correlates with hippocampal expression of inflammatory markers, TLR- 4 protein $\left(\mathrm{r}^{2}=-0.693, \mathrm{p}<0.01\right)$, TNF- $\alpha$ protein $\left(r^{2}=-0.538, p<0.01\right)$, and IL-1ß protein $\left(r^{2}=-0.447, p<0.01\right)$. In addition, there was a significant correlation between hippocampal TLR-4 protein with TNF- $\alpha$ protein $\left(\mathrm{r}^{2}=0.581, \mathrm{p}<0.01\right)$ and IL- $1 ß$ protein $\left(r^{2}=0.649, p<0.01\right)$.

\section{DISCUSSION}

The concurrence of depression with diabetes resembles, adding fuel to the fire. Both diseases are closely associated in a reciprocal manner, leading to significant morbidity and mortality with an evidence of a pro-inflammatory state underlying pathophysiology of both diseases. This study was designed to evaluate the effects of two different antidepressant drugs on hippocampal neuroinflammation that has been proposed by many studies as a corner stone in the pathogenesis of depression and to justify the preference of one antidepressant over the other in the management of comorbid depression with diabetes. To the best of our knowledge, this is the first work to assess TLR- 4 and BDNF expression in the hippocampus of rats exposed to a combined model of DM and depression.

The results of this work alongside our previously published work [16] showed that the metabolic abnormalities induced by type 2 DM were more prominent with CRS accompanied by decreased body weight gain and increased serum corticosterone levels which indicate the absence of adaptive response to stress. Chronic treatment with FLU and IMIP reversed these changes in a comparable manner.

The increased immobility time with decreased struggling and swimming times is typically used to infer increased "depression" in rats [26], while reduced active interaction time in SIT suggests impaired exploratory activity with CRS-induced freezing, which is an index of generalized anxiety associated with depression in rats and this is consistent with the previous studies which detected CRS-induced anxiety and depressivelike behavior [27].

The previous studies have shown that diabetic animals presented higher depressive-like behavior in FST [28]. STZ diabetic rats showed decreased exploratory activity in OFT with a significant increase in immobility time in FST [29]. In this regard, the diabetes-induced reduction of hippocampal neurogenesis (reduced BDNF) implies a potential mechanism for diabetes-related depression and cognitive dysfunction.

FLU and IMIP are well known for their antidepressant activity through increasing the bioavailability of biogenic amines and hippocampal BDNF and correcting the hypothalamo-pituitary adrenal axis dysfunction as indicated by the decline of serum corticosterone level [30]. Literature data show that the chronic IMIP treatment improved chronic stress/ high fat diet-related behavioral changes [31].

The present work showed a significant increase in hippocampal expression of TLR- 4 , TNF- $\alpha$, and IL1- $\beta$ alongside a decrease in BDNF expression in diabetic and stressed rats with a significant correlation between increased expression of pro-inflammatory cytokines; TLR-4, TNF- $\alpha$, and IL1- $\beta$ with decreased BDNF expression.

Chronic inflammation underlies insulin resistance and type 2 DM. In this context, monocytes isolated from diabetic patients showed increased TLR-4 expression and TLR-mediated inflammation, this was significantly correlated with HbA1c levels [32]. TLR-4 expression was increased in diabetic nephropathy patients [33]. Levels of TNF- $\alpha$ were significantly elevated in the blood of patients with type 2 DM in association with increased blood sugar indices and insulin resistance [34].

Consistently; signs of hippocampal inflammation were noticed in diabetic rats with an elevation of inflammatory markers in the 


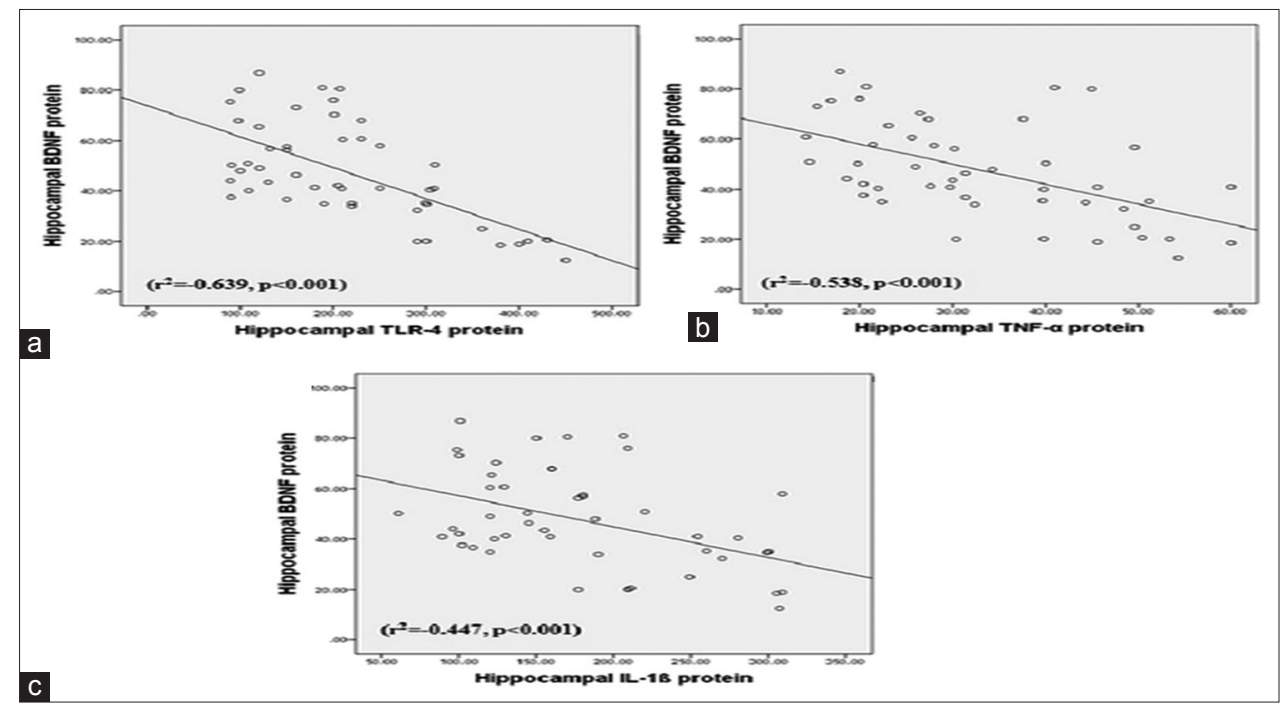

Fig. 5: (a-c) Pearson's correlation between hippocampal brain-derived neurotrophic factor protein with toll-like receptor-4, tumor necrosis factor- $\alpha$, and interleukin-1ß proteins in the present study

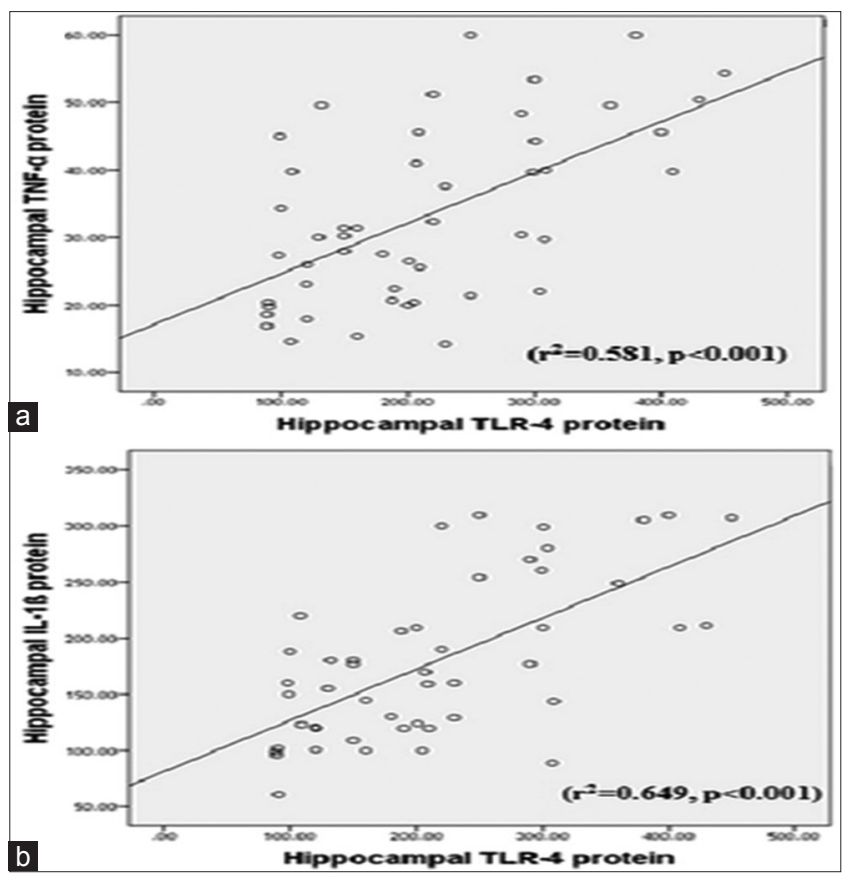

Fig. 6: (a and b) Pearson's correlation between hippocampal toll-like receptor- 4 protein with tumor necrosis factor- $\alpha$ and interleukin-1ß proteins in the present study

hippocampus [35]. Previous studies reported that chronic mild stress could stimulate TLR-4 signaling pathway in the prefrontal cortex with increased levels of TNF- $\alpha$, IL-1 $\beta$ and COX-2 [36]. In addition, corticosteroids, TNF- $\alpha$, and IL- 1 ß serum levels were significantly higher in individuals with psychological symptoms [37] and animals treated with chronic stress models [38].

In a previous work, we have concluded that TLR- 4 and subsequent cytokine production may underlie diabetes and psychological stress associated vascular complications [16]. The results of this work emphasize that TLR-4 activation not only underlies complications but it may be also involved in the pathogenesis of both depression and DM.

Higher levels of cytokines could result in disruption of hippocampal function and hippocampal neurodegeneration [39]. Studies of TLR4- deficient mice suggest that TLR4 signaling has a negative impact on hippocampus-dependent cognitive function [40]. In addition, it has been shown that systemic administration of TNF- $\alpha$ reduces hippocampal cell proliferation [41].

It is documented that an alteration in BDNF contributes to the pathophysiology of depression and DM. Decreased mRNA levels of BDNF in both hippocampus and prefrontal cortex (PFC) were confirmed by postmortem tissue from suicide subjects [42]. In addition, a decrease in BDNF concentration has been strongly linked to type 2 DM. BDNF was reported to improve glucose metabolism and insulin sensitivity [43]. Pro-inflammatory cytokines negatively regulate hippocampal BDNF expression and signal transduction [44]. There is a bidirectional relationship between BDNF and cytokines with a plausible role for this interaction in the etiology of major depressive disorders [45]. Accordingly, administration of lipopolysaccharide (LPS), a major bacterial TLR-4 ligand, caused cognitive impairment in animal models through increased expression of pro-inflammatory cytokines alongside a reduction in BDNF levels in the hippocampus [40].

Factors such as lipids and cytokines provide crosstalk between inflammatory and metabolic signaling pathways that contribute to the risk of developing DM and depression. Chronic inflammation is a common factor in the pathogenesis of insulin resistance and type $2 \mathrm{DM}$, the activation of TLR- 4 by free fatty acids, observed in type $2 \mathrm{DM}$, and subsequent upregulation of intracellular inflammatory pathways establish a link between the innate immunity, insulin resistance, type $2 \mathrm{DM}$, and depression. Mature human adipocytes express the LPS receptor, TLR-4, with activation leading to the secretion of TNF- $\alpha$ [46]. Indeed, numerous studies consistently demonstrate that TLR-4 deficiency protects against the development of diet-induced obesity and insulin resistance [47].

The activation of TLR- 4 and the transcription factor NF- $\mathrm{KB}$ in microglia and macrophages, which induces the expression of pro-inflammatory cytokines and the production of nitric oxide (NO), may have a detrimental effect on the hippocampal level of BDNF, and this may play critical roles in the pathogenesis of depression.

Chronic treatment with FLU and IMIP induced a significant reduction in hippocampal TLR-4 expression with a reduction in TNF- $\alpha$ and IL-1ß level in diabetic rats. FLU has been shown to reduce the stimulated proliferation of T-lymphocytes [48], it decreases NO synthesis and iNOS mRNA expression in microglial cells [49] and exerts modulatory effects on macrophages directing these cells toward anti-inflammatory 
activity [50]. FLU reduced TLR expression with subsequent reduction in cytokine levels in a murine model of rheumatoid arthritis [51].

As for IMIP was able to reverse the alterations on TNF- $\alpha$ and IL-1ß in serum and cerebrospinal fluid of rats submitted to an animal model of maternal deprivation [52]. It also enhances the production of the negative immune-regulator IL-10 in rats subjected to FST induced stress [53]. IMIP inhibits NO and TNF- $\alpha$ secretion by mixed glial cell cultures [54]. In a recent study, IMIP treatment induced a decline in the gene expression of TNF- $\alpha$ induced by LPS/CMS protocol [55].

\section{CONCLUSION}

This work implies that diabetes- and psychological stress-induced behavioral effects are, at least, partially the result of a chronic inflammatory condition. In this context, TLR-4 and subsequent cytokine production with disruption of hippocampal BDNF appear as pivotal players in the pathogenesis of this condition. To the best of our knowledge, this is the first work to assess the relation between TLR-4 and BDNF expression in the hippocampus of rats exposed to a combined model of DM and depression.

The results of this work alongside our previous work elucidate that chronic treatment with FLU and IMIP are comparable as regards their antidepressant and anti-inflammatory actions. FLU has a favorable effect over IMIP on metabolic and vascular aberrations associated with DM and CRS in Wistar rats, and this may suggest a preferable role of FLU over IMIP in the management of comorbid depression in diabetic subjects.

\section{REFERENCES}

1. Ramanna MK, Ruckmani A, Janti SS, Eerike M, Prabu RL. Burden of therapy in patients suffering from diabetes mellitus and hypertension. Int J Pharm Pharm Sci 2017;9:210-5.

2. Whiting DR, Guariguata L, Weil C, Shaw J. IDF diabetes atlas: Global estimates of the prevalence of diabetes for 2011 and 2030. Diabetes Res Clin Pract 2011;94:311-21.

3. Rubin RR, Ma Y, Marrero DG, Peyrot M, Barrett-Connor EL, Kahn SE, et al. Elevated depression symptoms, antidepressant medicine use, and risk of developing diabetes during the diabetes prevention program. Diabetes Care 2008;31:420-6.

4. Gomez R, Huber J, Tombini G, Barros HM. Acute effect of different antidepressants on Glycemia in diabetic and non-diabetic rats. Braz J Med Biol Res 2001;34:57-64.

5. Anderson RJ, Gott BM, Sayuk GS, Freedland KE, Lustman PJ. Antidepressant pharmacotherapy in adults with Type 2 diabetes: Rates and predictors of initial response. Diabetes Care 2010;33:485-9.

6. Andersohn F, Schade R, Suissa S, Garbe E. Long-term use of antidepressants for depressive disorders and the risk of diabetes mellitus. Am J Psychiatry 2009;166:591-8

7. Paile-Hyvärinen M, Wahlbeck K, Eriksson JG. Quality of life and metabolic status in mildly depressed patients with Type 2 diabetes treated with paroxetine: A double-blind randomised placebo controlled 6-month trial. BMC Fam Pract 2007;8:34.

8. Yoshii A, Constantine-Paton M. Postsynaptic BDNF-trkB signaling in synapse maturation, plasticity, and disease. Dev Neurobiol 2010;70:304-22.

9. Duric V, McCarson KE. Hippocampal neurokinin-1 receptor and brainderived neurotrophic factor gene expression is decreased in rat models of pain and stress. Neuroscience 2005;133:999-1006.

10. Ola MS, Nawaz MI, El-Asrar AA, Abouammoh M, Alhomida AS. Reduced levels of brain derived neurotrophic factor (BDNF) in the serum of diabetic retinopathy patients and in the retina of diabetic rats. Cell Mol Neurobiol 2013;33:359-67.

11. Engum A. The role of depression and anxiety in onset of diabetes in a large population-based study. J Psychosom Res 2007;62:31-8.

12. Kaisho T, Akira S. Regulation of dendritic cell function through tolllike receptors. Curr Mol Med 2003;3:373-85.

13. Okun E, Griffioen K, Barak B, Roberts NJ, Castro K, Pita MA, et al. Toll-like receptor 3 inhibits memory retention and constrains adult hippocampal neurogenesis. Proc Natl Acad Sci U S A 2010;107:15625-30

14. Chakravarty S, Herkenham M. Toll-like receptor 4 on nonhematopoietic cells sustains CNS inflammation during endotoxemia, independent of systemic cytokines. J Neurosci 2005;25:1788-96.

15. Schwartz EA, Zhang WY, Karnik SK, Borwege S, Anand VR, Laine PS, et al. Nutrient modification of the innate immune response: A novel mechanism by which saturated fatty acids greatly amplify monocyte inflammation. Arterioscler Thromb Vasc Biol 2010;30:802-8.

16. Habib M, Shaker S, El-Gayar N, Aboul-Fotouh S. The effects of antidepressants "fluoxetine and imipramine" on vascular abnormalities and toll-like receptor-4 expression in diabetic and non-diabetic rats exposed to chronic stress. PLoS One 2015;10:e0120559.

17. Zhang Y, Woodruff M, Zhang Y, Miao J, Hanley G, Stuart C, et al. Toll-like receptor 4 mediates chronic restraint stress-induced immune suppression. J Neuroimmunol 2008;194:115-22.

18. Aboul-Fotouh S, Elgayar N. Atypical antipsychotics such as risperidone, but not paliperidone, worsen vascular endothelial function via upregulation of adhesion molecules VCAM-1, ICAM-1, and E-selectin in diabetic rats. Can J Physiol Pharmacol 2013;91:1119-26.

19. Aboul-Fotouh S. Chronic treatment with coenzyme Q10 reverses restraint stress-induced anhedonia and enhances brain mitochondrial respiratory chain and creatine kinase activities in rats. Behav Pharmacol 2013;24:552-60.

20. Aboul-Fotouh S. Coenzyme Q10 displays antidepressant-like activity with reduction of hippocampal oxidative/nitrosative DNA damage in chronically stressed rats. Pharmacol Biochem Behav 2013;104:105-12.

21. Crestani CC, Tavares RF, Guimarães FS, Correa FM, Joca SR, Resstel LB, et al. Chronic fluoxetine treatment alters cardiovascular functions in unanesthetized rats. Eur J Pharmacol 2011;670:527-33.

22. Bekris S, Antoniou K, Daskas S, Papadopoulou-Daifoti Z. Behavioural and neurochemical effects induced by chronic mild stress applied to two different rat strains. Behav Brain Res 2005;161:45-59.

23. Tõnissaar M, Mällo T, Eller M, Häidkind R, Kõiv K, Harro J, et al. Rat behavior after chronic variable stress and partial lesioning of 5-HT-ergic neurotransmission: Effects of citalopram. Prog Neuropsychopharmacol Biol Psychiatry 2008;32:164-77

24. File SE, Hyde JR. Can social interaction be used to measure anxiety? Br J Pharmacol 1978;62:19-24.

25. Bradford MM. A rapid and sensitive method for the quantitation of microgram quantities of protein utilizing the principle of protein-dye binding. Anal Biochem 1976;72:248-54.

26. Porsolt RD, Bertin A, Jalfre M. Behavioral despair in mice: A primary screening test for antidepressants. Arch Int Pharmacodyn Ther 1977;229:327-36.

27. Aboul-Fotouh S. Behavioral effects of nicotinic antagonist mecamylamine in a rat model of depression: Prefrontal cortex level of BDNF protein and monoaminergic neurotransmitters. Psychopharmacology (Berl) 2015;232:1095-105.

28. Ceretta LB, Réus GZ, Stringari RB, Ribeiro KF, Zappellini G, Aguiar BW, et al. Imipramine treatment reverses depressivelike behavior in alloxan-diabetic rats. Diabetes Metab Res Rev 2012;28:139-44.

29. Haider S, Ahmed S, Tabassum S, Memon Z, Ikram M, Haleem DJ, et al. Streptozotocin-induced insulin deficiency leads to development of behavioral deficits in rats. Acta Neurol Belg 2013;113:35-41.

30. Takano K, Yamasaki H, Kawabe K, Moriyama M, Nakamura Y. Imipramine induces brain-derived neurotrophic factor mRNA expression in cultured astrocytes. J Pharmacol Sci 2012;120:176-86.

31. Ismail B, Aboul-Fotouh S, Mansour AA, Shehata HH, Salman MI, Ibrahim EA, et al. Behavioural, metabolic, and endothelial effects of the TNF- $\alpha$ suppressor thalidomide on rats subjected to chronic mild stress and fed an atherogenic diet. Can J Physiol Pharmacol 2014;92:375-85.

32. Dasu MR, Devaraj S, Park S, Jialal I. Increased toll-like receptor (TLR) activation and TLR ligands in recently diagnosed Type 2 diabetic subjects. Diabetes Care 2010;33:861-8

33. Kuwabara T, Mori K, Mukoyama M, Kasahara M, Yokoi H, Saito Y, et al. Exacerbation of diabetic nephropathy by hyperlipidaemia is mediated by toll-like receptor 4 in mice. Diabetologia 2012;55:2256-66.

34. Saad EA, Habib SA, Refai WA, Elfayoumy AA. Malondialdehyde, adiponectin, nitric oxide, C-reactive protein, tumor necrosis factoralpha and insulin resistance relationships and inter-relationships in Type 2 diabetes early stage. Is metformin alone adequate in this stage? Int J Pharm Pharm Sci 2017;9:176-81.

35. Giribabu N, Srinivasarao N, Swapna Rekha S, Muniandy S, Salleh N. Centella asiatica attenuates diabetes induced hippocampal changes in experimental diabetic rats. Evid Based Complement Alternat Med 2014:2014:592062.

36. Gárate I, García-Bueno B, Madrigal JL, Bravo L, Berrocoso E, Caso JR, et al. Origin and consequences of brain toll-like receptor 
4 pathway stimulation in an experimental model of depression. $\mathrm{J}$ Neuroinflammation 2011;8:151.

37. Yasui T, Maegawa M, Tomita J, Miyatani Y, Yamada M, Uemura H, et al. Association of serum cytokine concentrations with psychological symptoms in midlife women. J Reprod Immunol 2007;75:56-62.

38. Mohamed BM, Aboul-Fotouh S, Ibrahim EA, Shehata H, Mansour AA, Yassin NA, et al. Effects of pentoxifylline, 7-nitroindazole, and imipramine on tumor necrosis factor- $\alpha$ and indoleamine 2,3-dioxygenase enzyme activity in the hippocampus and frontal cortex of chronic mildstress-exposed rats. Neuropsychiatr Dis Treat 2013;9:697-708.

39. Rothenburg LS, Herrmann N, Swardfager W, Black SE, Tennen G, Kiss A, et al. The relationship between inflammatory markers and post stroke cognitive impairment. J Geriatr Psychiatry Neurol 2010;23:199-205.

40. Vasconcelos AR, Yshii LM, Viel TA, Buck HS, Mattson MP, Scavone C, et al. Intermittent fasting attenuates lipopolysaccharide-induced neuroinflammation and memory impairment. J Neuroinflammation 2014;11:85.

41. Seguin JA, Brennan J, Mangano E, Hayley S. Proinflammatory cytokines differentially influence adult hippocampal cell proliferation depending upon the route and chronicity of administration. Neuropsychiatr Dis Treat 2009;5:5-14.

42. Dwivedi Y, Rizavi HS, Conley RR, Roberts RC, Tamminga CA, Pandey GN, et al. Altered gene expression of brain-derived neurotrophic factor and receptor tyrosine kinase B in postmortem brain of suicide subjects. Arch Gen Psychiatry 2003;60:804-15.

43. Arentoft A, Sweat V, Starr V, Oliver S, Hassenstab J, Bruehl H, et al. Plasma BDNF is reduced among middle-aged and elderly women with impaired insulin function: Evidence of a compensatory mechanism. Brain Cogn 2009; 71:147-52.

44. Barrientos RM, Higgins EA, Sprunger DB, Watkins LR, Rudy JW, Maier SF, et al. Memory for context is impaired by a post context exposure injection of interleukin-1 beta into dorsal hippocampus. Behav Brain Res 2002;134:291-8.

45. Lotrich FE, Albusaysi S, Ferrell RE. Brain-derived neurotrophic factor serum levels and genotype: Association with depression during interferon- $\alpha$ treatment. Neuropsychopharmacology 2013;38:985-95.
46. Bès-Houtmann S, Roche R, Hoareau L, Gonthier MP, Festy F, Caillens H, et al. Presence of functional TLR2 and TLR4 on human adipocytes. Histochem Cell Biol 2007;127:131-7.

47. Radin MS, Sinha S, Bhatt BA, Dedousis N, O'Doherty RM. Inhibition or deletion of the lipopolysaccharide receptor toll-like receptor-4 confers partial protection against lipid-induced insulin resistance in rodent skeletal muscle. Diabetologia 2008;51:336-46.

48. Diamond M, Kelly JP, Connor TJ. Antidepressants suppress production of the th1 cytokine interferon-gamma, independent of monoamine transporter blockade. Eur Neuropsychopharmacol 2006;16:481-90.

49. Liu D, Wang Z, Liu S, Wang F, Zhao S, Hao A, et al. Anti-inflammatory effects of fluoxetine in lipopolysaccharide(LPS)-stimulated microglial cells. Neuropharmacology 2011;61:592-9.

50. Roman A, Kuśmierczyk J, Klimek E, Rogóż Z, Nalepa I. Effects of coadministration of fluoxetine and risperidone on properties of peritoneal and pleural macrophages in rats subjected to the forced swimming test. Pharmacol Rep 2012;64:1368-80.

51. Sacre S, Medghalchi M, Gregory B, Brennan F, Williams R. Fluoxetine and citalopram exhibit potent anti-inflammatory activity in human and murine models of rheumatoid arthritis and inhibit toll-like receptors. Arthritis Rheum 2010;62:683-93.

52. Réus GZ, Dos Santos MA, Abelaira HM, Ribeiro KF, Petronilho F, Vuolo F, et al. Imipramine reverses alterations in cytokines and BDNF levels induced by maternal deprivation in adult rats. Behav Brain Res 2013;242:40-6.

53. Kubera M, Basta-Kaim A, Budziszewska B, Rogóz Z, Skuza G, Leskiewicz M, et al. Effect of amantadine and imipramine on immunological parameters of rats subjected to a forced swimming test. Int J Neuropsychopharmacol 2006;9:297-305.

54. Bielecka AM, Obuchowicz E. Imipramine and fluoxetine influence phenotype of microglial cells in the rat primary mixed glial cell cultures. Pharmacol Rep 2011;63:589-90.

55. Elgarf AS, Aboul-Fotouh S, Abd-Alkhalek HA, El Tabbal M, Hassan AN, Kassim SK, et al. Lipopolysaccharide repeated challenge followed by chronic mild stress protocol introduces a combined model of depression in rats: Reversibility by imipramine and pentoxifylline. Pharmacol Biochem Behav 2014;126:152-62. 